\title{
EFFECTS OF DRYING TEMPERATURE AND MICROWAVE POWER ON QUALITY CHARACTERISTICS OF TURKEY BREAST SLICES
}

\author{
Elif Aykın Dinçer* \\ Department of Food Engineering, Engineering Faculty, Akdeniz University, Antalya
}

Received / Geliş: 23.09.2021; Accepted / Kabul: 27.01.2022; Published online / Online bask1: 22.02.2022

Aykern-Dincer, E. (2022). Effects of drying temperature and microwave power on quality characteristics of turkey breast slices. GIDA (2022) 47(2) 147-156 doi: 10.15237/gida.GD21127.

Aykın-Dinçer, E. (2022). Kurutma sıcaklığ1 ve mikrodalga gücünün hindi göğüs dilimlerinin kalite özelliklerine etkileri. GIDA (2022) 47(2) 147-156 doi: 10.15237/gida.GD21127.

\begin{abstract}
In this study, spiced turkey slices were dried at different temperatures $\left(60\right.$ and $\left.70^{\circ} \mathrm{C}\right)$ and microwave powers $(0,180$ and $360 \mathrm{~W}$ at fixed product weight) and physical, chemical, microbiological and sensory quality characteristics of these dried slices were determined. The turkey slices dried at these conditions had an average moisture content of $25 \%$, an $\mathrm{a}_{\mathrm{w}}$ value of 0.72 , a $\mathrm{pH}$ value of 6.02 , and a thiobarbituric acid reactive substance $(T B A R S)$ value of $15.77 \mu \mathrm{mol} \mathrm{MDA} / \mathrm{kg}$. It was determined that the cutting force value of the samples increased to $56.14 \mathrm{~N}$ depending on the temperature increase and to $59.12 \mathrm{~N}$ depending on the increase in microwave power. In addition, it was found that the $L^{*}$ value of the samples decreased significantly $(p<0.01)$ as the microwave power increased. Furthermore, the microbial quality was better in samples applied at $70^{\circ} \mathrm{C}$ drying temperature and $360 \mathrm{~W}$ microwave power.
\end{abstract}

Keywords: Drying, hot air, microwave power, temperature, turkey breast meat

\section{KURUTMA SICAKLIĞI VE MİKRODALGA GÜCÜNÜN HİNDİ GÖĞÜS DİLİMLERİNINN KALİTE ÖZELLIKKLERİNE ETKILLERİ}

\section{ÖZ}

Bu çalışmada, baharatlanmış hindi dilimleri farklı sıcaklıklarda $\left(60\right.$ ve $\left.70^{\circ} \mathrm{C}\right)$ ve mikrodalga güçlerinde (sabit ürün ağırlığında 0,180 ve $360 \mathrm{~W}$ ) kurutulmuş ve bu kurutulmuş dilimlerin fiziksel, kimyasal, mikrobiyolojik ve duyusal kalite karakteristikleri belirlenmiştir. Bu koşullarda kurutulmuş hindi dilimlerinin ortalama nem içeriği $\% 25, a_{w}$ değeri $0.72, \mathrm{pH}$ değeri 6.02 ve tiyobarbitürik asit reaktif maddeleri $(T B A R S)$ değeri $15.77 \mu \mathrm{mol} \mathrm{MDA} / \mathrm{kg}$ idi. Örneklerin kesilme kuvveti değerinin, sicaklık artışına bağlı olarak 56.14 N'ye, mikrodalga gücündeki artsşa bağlı olarak 59.12 N'ye yükseldiği tespit edilmiştir. Ayrıca, mikrodalga gücü arttıkça örneklerin $L^{*}$ değerinin önemli düzeyde $(p<0.01)$ azaldığı bulunmuştur. Buna ilaveten, mikrobiyal kalite $70^{\circ} \mathrm{C}$ kurutma sıcaklığı ve $360 \mathrm{~W}$ mikrodalga gücü uygulanan örneklerde daha iyi olmuştur.

Anahtar kelimeler: Kurutma, sıcak hava, mikrodalga gücü, sıcaklık, hindi göğüs eti

\footnotetext{
${ }^{*}$ Yazışmalardan sorumlu yazar / Corresponding author;

$\square$ : elifaykin@akdeniz.edu.tr

(D): (+90) 2423104345

且: (+90) 2422274564

Elif Aykın Dinçer; ORCID no: 0000-0003-4427-9819
} 


\section{INTRODUCTION}

Dried meat products are an important part of snack foods as they have low water content, can be stored for a long time, are small and can be carried easily. These meat products are usually obtained by being dried using hot air after they are salted or cured (Qu et al., 2020). However, in recent years, the orientation towards alternative drying technologies has increased as the traditional method of drying in hot air entails high energy costs, as well as adversely affecting the quality of the product in drying heat-sensitive foods such as meat (Aykın-Dinçer and Erbaş, 2019). As an alternative method, microwaveassisted drying in hot air saves energy, has a short processing time and therefore costs less to operate (Półtorak et al., 2015). Moreover, as microwave application equally heats every point on the meat products, shrinkage, surface hardening and browning reactions that may occur in the final product can be prevented and product quality can be improved. A study done by $\mathrm{Fu}$ et al. (2015) found that TBARS values of samples that were dried using a microwave and microwave-vacuum methods were lower compared to those that were dried in hot air. However, in the study of Chaijan et al. (2017) that compared two different methods, microwave and sun-drying, a more intense brown color was detected in sun-dried meat samples.

With increasing interest in poultry meat worldwide, turkey meat has become the second most produced and consumed poultry meat after chicken meat. Turkey's turkey meat production increased 3.6 times between 2000 and 2018 and increased to 69,536 tons in 2018 (FAOSTAT, 2020). As turkey meat has a lower cholesterol and total fat content than beef, and a higher polyunsaturated fatty acids content, as well as a neutral taste and smooth texture and many other features, it has been used as a substitute for red meat in the production of various meat products (Ensoy et al., 2010; Yalçın and Şeker, 2016; Zampiga et al., 2019). On the other hand, turkey meat, whose consumption is very important for public health, has the risk of rapid microbiological deterioration due to its high water content and rich nutrients (Anaraki et al., 2020). For this reason, it is made more durable with the application of pasteurization, sterilization, cooling, freezing and drying processes and it is converted into turkey meat products that have a longer shelf life. There are a limited number of studies in the literature in which turkey breast meat is dried using different methods (Porto-Fett et al., 2009; Cumhur et al., 2016). In this study, spiced turkey breast meat slices were dried using microwave-assisted hot air drying method at different temperatures $\left(60\right.$ and $\left.70^{\circ} \mathrm{C}\right)$ and microwave powers $(0,180$, and $360 \mathrm{~W})$, and the physical, chemical, microbiological and sensory properties of the dried product were analyzed.

\section{MATERIALS AND METHODS}

\section{Spicing and drying of turkey slices}

Turkey breast slices used as raw material (about $66.40 \mathrm{~mm} \times 31.86 \mathrm{~mm} \times 3.79 \mathrm{~mm}$ ) were obtained from AntBahar Group of Companies (Antalya, Turkey). First, the turkey slices were spiced with a mixture $(2 \mathrm{~g} / 100 \mathrm{~g}$ meat $)$ that contains a certain proportion of salt $(0.25 \mathrm{~g} / \mathrm{g}$ mixture), thyme (0.5 $\mathrm{g} / \mathrm{g}$ mixture), black pepper (0.125 g/g mixture) and red pepper $(0.125 \mathrm{~g} / \mathrm{g}$ mixture). The spiced slices $(9.32 \pm 1.84 \mathrm{~g})$ were flipped every $15 \mathrm{~min}$ at $+4^{\circ} \mathrm{C}$ to allow salt diffusion to occur for $1 \mathrm{~h}$.

The spiced turkey breast slices were placed in a single row on baking paper and then dried in a compact oven with microwave (Siemens HB86K575, Germany). This oven was adjusted simultaneously to the air temperature and microwave power values. Applications were carried out using a constant airspeed $(1.0 \mathrm{~m} / \mathrm{s})$ at 2 different air temperatures $\left(60\right.$ and $\left.70{ }^{\circ} \mathrm{C}\right)$ and 3 different microwave powers $(0,180$ and $360 \mathrm{~W})$. For drying applications with different temperature and microwave power, 150 turkey slices ( 25 slices $\times 2$ temperatures $\times 3$ powers) in one replication, and a total of 300 turkey slices $(150$ slices $\times 2$ replications) because of two replications carried out for all analyses were dried. Drying process was terminated when the moisture content of the samples fell below 30\%. Therefore, drying times of the spiced slices were determined as 225,60 and $45 \mathrm{~min}$ at $60^{\circ} \mathrm{C}$ and 135,45 and $30 \mathrm{~min}$ at $70^{\circ} \mathrm{C}$ for 0,180 and $360 \mathrm{~W}$ respectively. 
Physical and microbiological analyses were performed immediately after the applications, while chemical analyses were performed in sets on samples taken from the applications and stored inside polyethylene packages at $-18^{\circ} \mathrm{C}$ in aerobic conditions.

\section{Chemical and physical analysis}

Moisture, protein, fat, ash, salt and $\mathrm{pH}$ analyses were performed on spiced fresh turkey breast slices as complementary analyses (AOAC, 2000). $a_{w}$ of fresh and dried slices was determined to be at $25^{\circ} \mathrm{C}$ using a water activity measuring device (Decagon Devices Inc., Pullman, WA, USA). Thiobarbituric acid reactive substances (TBARS) that were created as a result of lipid oxidation in dried samples were determined spectrophotometrically and the results were expressed in $\mu \mathrm{mol}$ malondialdehyde (MDA) $/ \mathrm{kg}$ samples (Lemon, 1975).

Color parameters $\left(L^{*}, a^{*}, b^{*}\right)$ of microwaveassisted hot air dried slices were measured at 8 different points on the sample surface by the CIELAB system using a CR-400 Chromameter (8 $\mathrm{mm}$ aperture; $2^{\circ}$ observer) (Konica Minolta, Japan). The $L^{*}$ value represents the brightness of the samples, the $a^{*}$ value represents the red-green color value and the $b^{*}$ value represents the yellowblue color value. The light source was a pulsed xenon lamp and the samples were measured using illuminant $\mathrm{D}_{65}$. The color device was calibrated by using its white ceramic plate before actual use.

The cutting force $(\mathrm{N})$ values of microwaveassisted hot air dried slices were determined with a TA.XT Plus Texture Analyzer (Stable Microsystems, UK) using Blade Set (HDP/BS) (Warner Bratzler, WB). The speed of probe, trigger force and load cell were $2 \mathrm{~mm} / \mathrm{s}, 10 \mathrm{~g}$ and $50 \mathrm{~kg}$, respectively. For analysis, four randomly selected slices were used. The change in size of the slices (given as percentage) was calculated by the difference of the length, width and thickness of the slices, measured with a caliper, before and after they were dried.

\section{Microbiological analysis}

For microbiological analysis, $10 \mathrm{~g}$ of sample was homogenized manually with $90 \mathrm{~mL}$ of alkali peptone water under aseptic conditions. Appropriate dilutions were prepared, and inoculation was performed using the pour plate method. Total aerobic mesophilic bacteria (TAMB) were enumerated on Plate Count Agar (PCA, Merck) and petri dishes were incubated at $30^{\circ} \mathrm{C}$ for $48 \mathrm{~h}$. Enterobacteriaceae were determined on Violet Red Bile Dextrose Agar (VRBD, Merck) after incubation at $30^{\circ} \mathrm{C}$ for $48 \mathrm{~h}$ under anaerobic conditions (Aneorocult A, Merck). Yeast-mold were enumerated on Potato Dextrose Agar (PDA, Merck) after incubation at $25^{\circ} \mathrm{C}$ for 5 days under aerobic conditions. The enumeration was performed in parallel petri dishes that contained colonies of 30-300 at the end of incubation. Data were represented as the $\log$ of colony forming units (cfu) per g of dried turkey (Maqsood et al., 2016).

\section{Sensory evaluation}

Sensory evaluation was performed in a ventilated room lighted with white fluorescent light by a group of eight panelists. Panelists were selected among experts on sensory evaluation that continue their post graduate studies at the Department of Food Engineering of the Faculty of Engineering, Akdeniz University. Panelists evaluated the six samples in a single session and the same panelists were used for each replication. Samples were identified with three-digit numbers and served to panelists randomly and also water and bread was given after each sample in order to neutralize the taste in mouth. Panelists evaluated the appearance, color, odor, flavor, structure, and overall acceptability using a hedonic scale of 9 (1: did not like at all, 9: liked very much) (Konieczny et al., 2007).

\section{Statistical analysis}

Two different drying temperatures $\left(60\right.$ and $\left.70^{\circ} \mathrm{C}\right)$ and three different microwave powers $(0,180$ and $360 \mathrm{~W}$ ) were selected as variables and experiments were designed according to a randomized complete block design with two replicates. The treatments were a fixed effect and replications were included in the model as a random effect. The data were tested by variance analysis, and significant means were compared with Duncan's multiple comparison test using SAS version 7 
(SAS Institute Inc., Cary, NC, USA). The values are presented as mean \pm standard error.

\section{RESULTS AND DISCUSSION}

Physicochemical properties of spiced raw turkey slices

Spiced raw turkey slices were found to contain $70.81 \pm 0.03 \%$ moisture, $24.56 \pm 0.24 \%$ protein, $2.62 \pm 0.18 \%$ fat, $2.01 \pm 0.02 \%$ ash and $0.95 \pm$ $0.02 \%$ salt on average. Average $\mathrm{pH}$ and water activity values of the spiced turkey slices were 6.32 \pm 0.012 and $0.987 \pm 0.001$ respectively. In this study, composition of the turkey slices prepared from breast muscle was found to be consistent with the literature findings (Yalçın and Şeker, 2016; Zampiga et al., 2019; Anaraki et al., 2020).

Moisture, $\mathrm{a}_{\mathrm{w}}, \mathrm{pH}$ and TBARS values of microwave-assisted hot air dried turkey slices Moisture, $a_{w}, \mathrm{pH}$ and TBARS values of turkey slices dried at different temperatures and microwave powers are presented in Table 1. It was determined that the temperature, microwave power and temperature $\mathrm{x}$ microwave power interaction had no significant $(p>0.05)$ effect on the moisture, $a_{w}$ and $\mathrm{pH}$ value of dried turkey slices.

Table 1. The moisture, $\mathrm{a}_{\mathrm{w}}, \mathrm{pH}$ and thiobarbituric acid-reactive substances (TBARS) values of microwave-assisted hot air dried turkey slices

\begin{tabular}{ccccc}
\hline & $\begin{array}{c}\text { Moisture } \\
(\%)\end{array}$ & $\mathrm{a}_{\mathrm{w}}$ & $\mathrm{pH}$ & $\begin{array}{c}\text { TBARS } \\
(\mu \mathrm{mol} \mathrm{MA} / \mathrm{kg})\end{array}$ \\
\hline $60^{\circ} \mathrm{C}, 0 \mathrm{~W}$ & $24.69 \pm 3.57$ & $0.777 \pm 0.03$ & $5.99 \pm 0.10$ & $9.84^{\mathrm{d}} \pm 0.10$ \\
$60^{\circ} \mathrm{C}, 180 \mathrm{~W}$ & $26.39 \pm 2.81$ & $0.722 \pm 0.04$ & $6.08 \pm 0.05$ & $13.51^{\mathrm{c}} \pm 0.13$ \\
$60^{\circ} \mathrm{C}, 360 \mathrm{~W}$ & $23.88 \pm 0.78$ & $0.656 \pm 0.04$ & $6.07 \pm 0.12$ & $13.64^{\mathrm{c}} \pm 0.48$ \\
$70^{\circ} \mathrm{C}, 0 \mathrm{~W}$ & $24.31 \pm 4.53$ & $0.811 \pm 0.06$ & $6.04 \pm 0.05$ & $13.47^{\mathrm{c}} \pm 0.05$ \\
$70^{\circ} \mathrm{C}, 180 \mathrm{~W}$ & $24.99 \pm 2.71$ & $0.694 \pm 0.09$ & $5.96 \pm 0.04$ & $20.19^{\mathrm{b}} \pm 0.03$ \\
$70^{\circ} \mathrm{C}, 360 \mathrm{~W}$ & $24.14 \pm 0.14$ & $0.664 \pm 0.02$ & $6.01 \pm 0.06$ & $23.97^{\mathrm{a}} \pm 0.09$ \\
$\mathrm{~T} \times \mathrm{M}$ & $N S$ & $N S$ & $N S$ & \\
\hline Temperature $\left(\mathrm{T},{ }^{\circ} \mathrm{C}, \mathrm{n}=6\right)$ & & & & \\
\hline 60 & $24.99 \pm 1.28$ & $0.718 \pm 0.03$ & $6.04 \pm 0.05$ & $12.33^{\mathrm{b}} \pm 0.80$ \\
70 & $24.48 \pm 1.37$ & $0.723 \pm 0.04$ & $6.00 \pm 0.03$ & $19.21^{\mathrm{a}} \pm 1.94$ \\
Significance & $N S$ & $N S$ & $N S$ & $* *$ \\
\hline Microwave power $(\mathrm{M}, \mathrm{W}, \mathrm{n}=4)$ & & & $11.65^{\mathrm{c}} \pm 1.05$ \\
\hline 0 & $24.50 \pm 2.36$ & $0.794 \pm 0.03$ & $6.01 \pm 0.05$ & $16.85^{\mathrm{b}} \pm 1.93$ \\
180 & $25.69 \pm 1.65$ & $0.708 \pm 0.04$ & $6.02 \pm 0.04$ & $18.80^{\mathrm{a}} \pm 2.99$ \\
360 & $24.01 \pm 0.33$ & $0.660 \pm 0.02$ & $6.04 \pm 0.06$ & $* *$ \\
\hline
\end{tabular}

a,b,c,d Means with different letters within the column indicate differences.

NS Not Significant $(p>0.05)$.

$* * p<0.01$.

It was found that the average moisture content of microwave-assisted hot air dried turkey slices is $25 \%, a_{w}$ is 0.72 and $\mathrm{pH}$ value is 6.02 . Therefore, it was determined that the meat product obtained in this study is in the class of medium moist foods (moisture \%: 15-50 and $a_{w}$ value: 0.6-0.9) and is much more resistant to microbial degradation than fresh turkey breast meat. It has also been determined in many studies on drying various meat slices at different temperatures that the temperature factor does not affect moisture, water activity and $\mathrm{pH}$ values (Jiang et al., 2016; Aykın-Dinçer and Erbaş, 2019). Unlike this study, it was reported in a study by Chaijan et al. (2017) that the moisture value of dried fish meat decreased from $30 \%$ to $28 \%$, and the $\mathrm{pH}$ value increased from 6.60 to 6.64 as microwave power increased. This difference is thought to be resulting from drying the turkey meat down to the same moisture content in all applied temperature $\left(60\right.$ and $70^{\circ} \mathrm{C}$ ) and microwave power $(1,180$ and $360 \mathrm{~W})$ factors. 
On the TBARS value, the temperature and microwave power factors were found to be effective at a level of $p<0.01$. It was determined that the TBARS value of the samples increased to $19.21 \mu \mathrm{mol} \mathrm{MDA} / \mathrm{kg}$ as the drying temperature increased and to $18.80 \mu \mathrm{mol} \mathrm{MDA} / \mathrm{kg}$ as the microwave power increased. The high temperature $\left(70^{\circ} \mathrm{C}\right)$ and microwave power $(360$ W) applied in this study triggered fat oxidation in the meat, and similar results were reported in several studies on meat drying (Inchingolo et al., 2013; Jiang et al., 2016). Zambiga et al. (2019) reported the TBARS value of raw turkey breast as $0.59 \mathrm{mg} \mathrm{MDA} / \mathrm{kg}$ meat $(8.19 \mu \mathrm{mol} \mathrm{MDA} / \mathrm{kg})$, which is quite low compared to the TBARS values of dried turkey breast meat. No extreme rancid taste resulting from an advanced level of oxidation was found in dried turkey slices. In line with the results of the study, it was also reported that off-flavor in cooked turkey breast meat can be detected when the TBARS value reaches the level of approximately $1.5 \mathrm{mg} \mathrm{MDA} / \mathrm{kg}$ of meat (Brunton et al., 2000). Also, the average TBARS value of dried turkey breast slices $(15.77 \mu \mathrm{mol}$ $\mathrm{MDA} / \mathrm{kg}$ ) was detected to be lower than TBARS value of cold-dried chicken breast slices ( $\mu \mathrm{mol}$ MDA 23.66/kg) (Aykın Dinçer, 2020), and it was evaluated that chicken breast containing higher amounts of fat $(3.70 \%)$ can be the cause of this case.

Cutting force and changes in size of microwave-assisted hot air dried turkey slices The cutting force value findings of turkey slices dried at different temperatures and microwave power are given in Table 2. The cutting force values for the samples were determined to vary between 20.63-66.07 N. In a study on the quality of jerky samples prepared from different meats, the cutting force value for jerky samples prepared from turkey meat was reported as $6.60 \mathrm{~kg}(64.72$ N) (Carr et al., 1997). It was determined that temperature and microwave power factors have a significant $(p<0.01)$ effect on the cutting force of dried turkey slices. It was found that the cutting force of samples that were rapidly dried at high temperature $\left(70^{\circ} \mathrm{C}\right)$ microwave power $(360 \mathrm{~W})$ was higher. This may be resulting from increased meat stiffness due to the denaturation of myofibrillar proteins such as myosin and actin during drying. Similar to the results of the study, the cutting force value of dried meat slices that are dried as the temperature (Aykın-Dinçer et al., 2020) and microwave power (Półtorak et al., 2015) increase was determined to be higher.

Table 2. Cutting force and changes in size of microwave-assisted hot air dried turkey slices

\begin{tabular}{|c|c|c|c|c|}
\hline & Cutting force $(\mathrm{N})$ & $\begin{array}{c}\text { Decrease in length } \\
(\%)\end{array}$ & $\begin{array}{c}\text { Decrease in width } \\
(\%)\end{array}$ & $\begin{array}{l}\text { Decrease in } \\
\text { thickness }(\%)\end{array}$ \\
\hline $60^{\circ} \mathrm{C}, 0 \mathrm{~W}$ & $20.63 \pm 0.01$ & $23.47 \pm 5.46$ & $30.59 \pm 1.00$ & $36.73 \pm 5.55$ \\
\hline $60^{\circ} \mathrm{C}, 180 \mathrm{~W}$ & $52.17 \pm 4.14$ & $37.98 \pm 2.35$ & $32.14 \pm 0.31$ & $35.60 \pm 0.14$ \\
\hline $60^{\circ} \mathrm{C}, 360 \mathrm{~W}$ & $52.18 \pm 1.55$ & $38.12 \pm 1.64$ & $31.70 \pm 4.22$ & $15.28 \pm 2.09$ \\
\hline $70^{\circ} \mathrm{C}, 0 \mathrm{~W}$ & $40.45 \pm 1.19$ & $28.50 \pm 0.76$ & $27.69 \pm 5.92$ & $36.88 \pm 1.58$ \\
\hline $70^{\circ} \mathrm{C}, 180 \mathrm{~W}$ & $61.90 \pm 2.47$ & $37.57 \pm 6.18$ & $28.76 \pm 1.71$ & $30.09 \pm 0.86$ \\
\hline $70^{\circ} \mathrm{C}, 360 \mathrm{~W}$ & $66.07 \pm 0.02$ & $42.63 \pm 4.79$ & $29.31 \pm 8.47$ & $26.93 \pm 6.61$ \\
\hline $\mathrm{T} \times \mathrm{M}$ & NS & NS & NS & NS \\
\hline \multicolumn{5}{|c|}{ Temperature $\left(\mathrm{T},{ }^{\circ} \mathrm{C}, \mathrm{n}=6\right)$} \\
\hline 60 & $41.66^{\mathrm{b}} \pm 6.75$ & $33.19 \pm 3.46$ & $31.48 \pm 1.16$ & $29.20 \pm 4.67$ \\
\hline 70 & $56.14^{\mathrm{a}} \pm 5.07$ & $36.23 \pm 3.31$ & $28.58 \pm 2.72$ & $31.30 \pm 2.56$ \\
\hline Significance & ** & NS & NS & NS \\
\hline \multicolumn{5}{|c|}{ Microwave power $(M, W, n=4)$} \\
\hline 0 & $30.54^{b} \pm 5.74$ & $25.98^{\mathrm{b}} \pm 2.68$ & $29.14 \pm 2.59$ & $36.80^{\mathrm{a}} \pm 2.35$ \\
\hline 180 & $57.03^{a} \pm 3.43$ & $37.78^{a} \pm 2.70$ & $30.45 \pm 1.21$ & $32.84^{\mathrm{a}} \pm 1.63$ \\
\hline 360 & $59.12^{a} \pm 4.06$ & $40.38^{a} \pm 2.44$ & $30.50 \pm 3.92$ & $21.10^{\mathrm{b}} \pm 4.40$ \\
\hline Significance & $* *$ & $*$ & NS & $*$ \\
\hline
\end{tabular}

a,b Means with different letters within the column indicate differences.

NS Not Significant $(p>0.05)$.

$* p<0.05$.

$* * p<0.01$. 
While the microwave power applied during drying has a significant $(\phi<0.05)$ effect on the decrease in length and thickness of dried turkey slices, it is found that temperature and temperature $\mathrm{x}$ microwave power interaction has an insignificant $(\phi>0.05)$ effect. In addition, it has been determined that the factors applied during the drying process have no significant effect on the decrease in width (Table 2). In this study, it was determined that rapidly dried slices at $360 \mathrm{~W}$ microwave power were shorter (high length decrease) and thicker (low thickness decrease). As microwave power increased at temperatures applied during drying $\left(60-70^{\circ} \mathrm{C}\right)$, denaturation of myofibrillar proteins increased and accordingly, high shrinkage of muscle fibers may have occurred. In a study on drying fish slices, it was reported that the rate of shrinkage of slices increase as microwave power increases (Duan et al., 2011).

\section{Color values of microwave-assisted hot air dried turkey slices}

The $L^{*}, a^{*}$ and $b^{*}$ color values of the turkey slices dried at different temperature and microwave power are given in Table 3 . While the microwave power and temperature $\mathrm{x}$ microwave power interaction had a $p<0.01$ level effect on the $L^{*}$ value of dried meat slices, the temperature value was found to had no significant $(p>0.05)$ effect. It was also detected that these factor and interaction applied during drying had no significant $(\phi>0.05)$ effect on $a^{*}$ and $b^{*}$ values.

Table 3. Color values $\left(L^{*}, a^{*}\right.$ and $\left.b^{*}\right)$ of microwave-assisted hot air dried turkey slices

\begin{tabular}{|c|c|c|c|}
\hline & $L^{*}$ & $a^{*}$ & $b^{*}$ \\
\hline $60^{\circ} \mathrm{C}, 0 \mathrm{~W}$ & $36.70^{\mathrm{bc}} \pm 1.50$ & $7.37 \pm 0.01$ & $20.40 \pm 0.79$ \\
\hline $60^{\circ} \mathrm{C}, 180 \mathrm{~W}$ & $38.00^{\mathrm{ab}} \pm 0.25$ & $8.37 \pm 0.50$ & $22.51 \pm 2.46$ \\
\hline $60^{\circ} \mathrm{C}, 360 \mathrm{~W}$ & $34.25^{c} \pm 0.07$ & $8.83 \pm 0.25$ & $22.56 \pm 0.50$ \\
\hline $70^{\circ} \mathrm{C}, 0 \mathrm{~W}$ & $40.16^{a} \pm 0.22$ & $6.64 \pm 0.71$ & $21.93 \pm 0.37$ \\
\hline $70^{\circ} \mathrm{C}, 180 \mathrm{~W}$ & $36.45^{b c} \pm 1.32$ & $7.16 \pm 0.70$ & $22.08 \pm 1.35$ \\
\hline $70^{\circ} \mathrm{C}, 360 \mathrm{~W}$ & $28.68^{\mathrm{d}} \pm 0.80$ & $8.21 \pm 0.42$ & $20.47 \pm 0.08$ \\
\hline $\mathrm{T} \times \mathrm{M}$ & ** & NS & NS \\
\hline \multicolumn{4}{|c|}{ Temperature $\left(T,{ }^{\circ} \mathrm{C}, \mathrm{n}=6\right)$} \\
\hline 60 & $36.32 \pm 0.80$ & $8.19 \pm 0.31$ & $21.82 \pm 0.82$ \\
\hline 70 & $35.09 \pm 2.18$ & $7.34 \pm 0.40$ & $21.49 \pm 0.49$ \\
\hline Significance & NS & NS & NS \\
\hline \multicolumn{4}{|c|}{ Microwave power $(M, W, n=4)$} \\
\hline 0 & $38.43^{a} \pm 1.17$ & $7.01 \pm 0.36$ & $21.17 \pm 0.57$ \\
\hline 180 & $37.22^{a} \pm 0.71$ & $7.76 \pm 0.49$ & $22.29 \pm 1.15$ \\
\hline 360 & $31.47^{b} \pm 1.64$ & $8.52 \pm 0.27$ & $21.51 \pm 0.64$ \\
\hline Significance & ** & NS & NS \\
\hline
\end{tabular}

a,b,c,d Means with different letters within the column indicate differences.

NS Not Significant $(p>0.05)$.

$* * p<0.01$.

The average $L^{*}, a^{*}$ and $b^{*}$ values of dried turkey breast slices were detected to be $35.71,7.77$ and 21.66 respectively. Zampiga et al. (2019) reported that average $L^{*}, a^{*}$ and $b^{*}$ values of raw turkey breast meats belonging to 2 different genotypes as 53.2, 3.18 and 0.77 , respectively. According to these results, it was evaluated that the brightness of the slices decreased (low $L^{*}$ value) and browning increased (high $a^{*}$ and $b^{*}$ value) due to dark pigments formed after microwave-assisted hot air drying.

As microwave power increases (from $0 \mathrm{~W}$ to 360 $\mathrm{W})$, the $L^{*}$ value of the samples decreases from 38.43 to 31.47 , meaning that their color darkens. Similarly, Özbay-Doğu (2016) reported that the 
$L^{*}$ value of samples decreased as microwave power increased (180W to $720 \mathrm{~W}$ ) during drying of round beef. In another study, the $L^{*}$ value of the meat samples that were dried at $100 \%$ microwave density (46.81) was detected to be lower than the meat samples dried at $30 \%$ microwave density (50.16) (Półtorak et al., 2015).

\section{Microbiological quality of microwave-} assisted hot air dried turkey slices

Enterobacteriaceae were not detected in dried turkey slices $(<2.00 \log \mathrm{cfu} / \mathrm{g})$ and it is thought that this group of microorganisms lost their viability due to the decrease in $\mathrm{a}_{\mathrm{w}}$ to about 0.72 during microwave-assisted hot air drying. Temperature and microwave power factors applied on TAMB count of samples during drying was found to be effective at the $p<0.01$ level and the interaction of these factors was found to be effective at the $p$ $<0.05$ level (Figure 1(a)). It was determined that only the microwave power $(\phi<0.01)$ had a significant effect on the yeast-mold count of meat slices (Figure 1(b)).

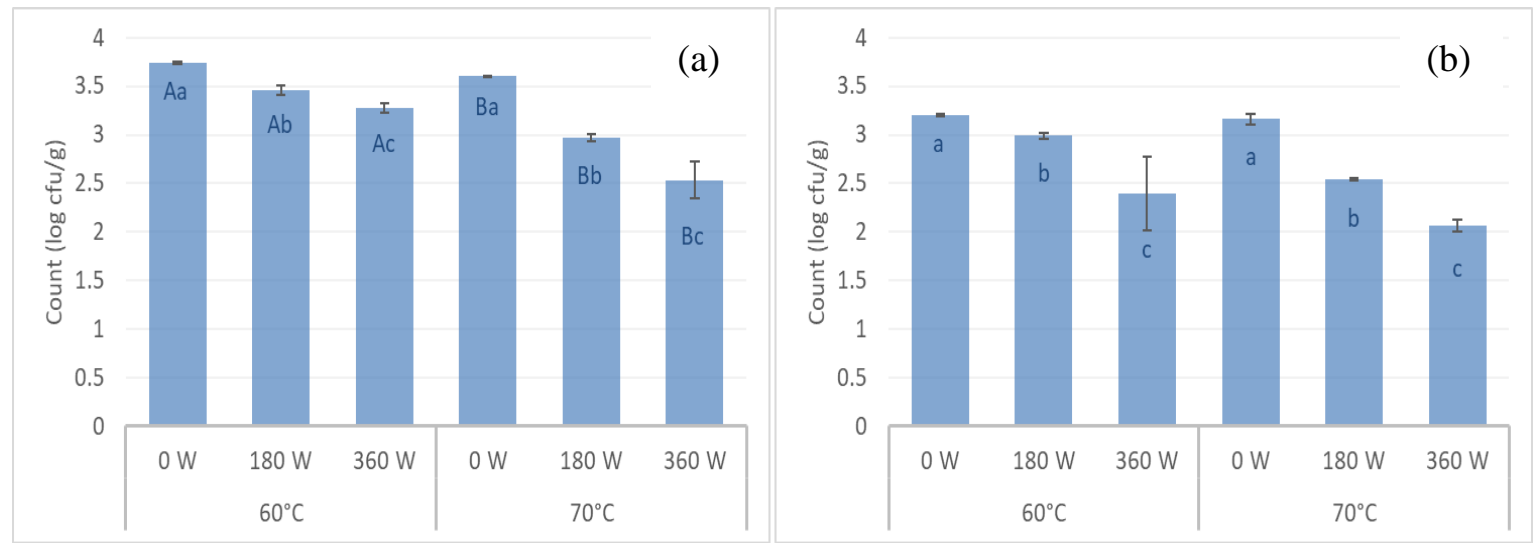

Figure 1. Changes in microbial quality of microwave-assisted hot air dried turkey slices under different drying conditions: (a) Total aerobic mesophilic bacteria; (b) Yeast-mold.

A,B Means with different letters within the temperatures indicate differences.

a,b,c Means with different letters within the microwave powers indicate differences.

Due to the increase in temperature and microwave power during drying, a significant decrease in the count of TAMB was detected (Figure 1(a)) and this may have been caused by further damage to the bacterial cell membrane and DNA in the protein structure. In addition, as the microwave power increased from $0 \mathrm{~W}$ to $360 \mathrm{~W}$, microwaves might create more edge effects and cause the microorganisms on the surface of the meat slices to be inactivated due to overheating. Ensoy et al. (2010) reported in their study that heat treatment (air temperature of $70^{\circ} \mathrm{C}$ ) reduced the count of TAMB in fermented turkey sausages by about $1.5 \mathrm{log}$. In another study, the TAMB count of turkey breast slices salted and freezedried up to $33 \%$ moisture content was reported as $3.35 \mathrm{log} \mathrm{cfu} / \mathrm{g}$ (Yalçın and Şeker, 2016). The average yeast-mold count of turkey slices dried in microwave-assisted hot air was $2.72 \log \mathrm{cfu} / \mathrm{g}$.
This is due to the high initial microbial loads of the slices or contamination during processing. It has also been found that the count of yeast-mold decreases as microwave power increases. Anaraki et al. (2020) reported that heat treatment applied to cured and vacuum-packed turkey breast meat is effective in reducing yeast-mold count.

\section{Sensory quality of microwave-assisted hot air dried turkey slices}

Sensory properties of turkey slices dried in microwave-assisted hot air are given in Figure 2(a) and Figure 2(b). In all drying conditions, the scores for the sensory properties of dried turkey slices were not below 5 (medium). Panelists found little difference between the sensory properties of the samples dried in 6 different ways. It was detected that the drying temperature did not affect $(\phi>0.05)$ other sensory properties of 
samples other than their appearance and color properties $(p<0.01)$ of samples, whereas microwave power only affected $(p<0.01)$ the appearance property.
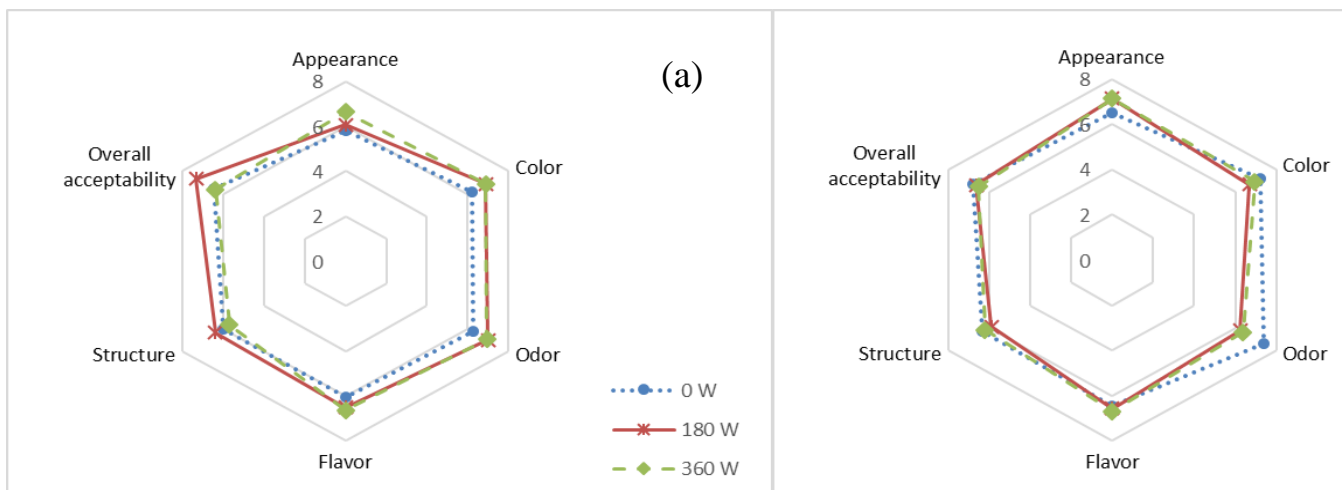

Figure 2. Changes in sensory properties of microwave-assisted hot air dried turkey slices under different drying conditions: (a) at $60^{\circ} \mathrm{C}$; (b) at $70^{\circ} \mathrm{C}$.

The highest scores of appearance and color were found in samples dried at a temperature of $70^{\circ} \mathrm{C}$ and a microwave power of $360 \mathrm{~W}$. This may be due to the darkening of the flesh color (Table 3) due to the increase in temperature and microwave power. Furthermore, the factors applied in this study were not effective $(p>0.05)$ on the overall acceptability scores of turkey slices dried using microwave-assisted hot air. Carr et al. (1997) also found no significant differences between jerky samples produced from beef and turkey in terms of flavor and overall acceptability properties. On the other hand, in other studies, high temperature (Choi et al., 2015) and high microwave power (Chen et al., 2014) applications have been reported to improve the sensory quality of dried meat samples.

\section{CONCLUSION}

Turkey slices were dried down to approximately $25 \%$ moisture content at different temperatures $\left(60^{\circ} \mathrm{C}\right.$ and $\left.70^{\circ} \mathrm{C}\right)$ and microwave power $(0,180$ and $360 \mathrm{~W})$, and it was detected that the $\mathrm{a}_{\mathrm{w}}$ value was 0.72 and the $\mathrm{pH}$ value was 6.02 . The TBARS value and cutting force of meat slices increased due to the increase in temperature and microwave power. Slices dried at high microwave power (360 W) were found to be thicker and less bright (low $L^{*}$ value). Microbial quality was determined to be better in samples dried at high temperature $\left(70^{\circ} \mathrm{C}\right)$ and microwave power $(360 \mathrm{~W})$.
This study shows that spiced turkey slices can be dried homogenously in a high quality and short time using the microwave-assisted hot air drying method. Since microwave application has a significant impact on drying and product quality, it is considered in a future study to combine different drying techniques with microwave application.

\section{CONFLICT OF INTEREST}

No potential conflict of interest was reported by the author.

\section{REFERENCES}

Anaraki, N.V., Abbasvali, M., Bonyadian, M. (2020). Effects of post-packaging pasteurization process on microbial, chemical, and sensory qualities of ready-to-eat cured vacuum-packed Turkey breast. J Food Saf, 40: e12776.

AOAC. (2000). Association of Official Analytical Chemists, Official Methods of Analysis, 17th edition. AOAC, Washington DC.

Aykın Dinçer, E. (2020). Some quality properties of cold dried chicken meat slices. GIDA-J Food, 45: 262-274.

Aykın-Dinçer, E., Erbaş, M. (2019). Quality characteristics of cold-dried beef slices. Meat Sci, 155: 36-42.

Aykın-Dinçer, E., Kılıç-Büyükkurt, Ö., Erbaş, M. (2020). Influence of drying techniques and 
temperatures on drying kinetics and quality characteristics of beef slices. Heat Mass Transfer, 56: 315-320.

Brunton, N.P., Cronin, D.A., Monahan, F.J., Durcan, R. (2000). Effect of postmortem ageing prior to cooking on lipid oxidation in cooked turkey. In: Frontiers of Flavour Science, Schieberle, P., Engel, K.H. (Eds.), Garching: Deutsche Forschungsanstalt für Lebensmittelchemie, pp. 545-548.

Carr, M.A., Miller, M.F., Daniel, D.R., Yarbrough, C.E., Petrosky, J.D., Thompson, L.D. (1997). Evaluation of the physical, chemical and sensory properties of jerky processed from emu, beef, and turkey. J Food Qual, 20: 419-425.

Chaijan, M., Panpipat, W., Nisoa, M. (2017). Chemical deterioration and discoloration of semidried tilapia processed by sun drying and microwave drying. Dry Technol, 35: 642-649.

Chen, F., Zhang, M., Mujumdar, A.S., Jiang, H., Wang, L. (2014). Production of crispy granules of fish: A comparative study of alternate drying techniques. Dry Technol, 32: 1512-1521.

Choi, Y.S., Ku, S.K., Park, J.D., Kim, H.J., Jang, A., Kim, Y.B. (2015). Effects of drying condition and binding agent on the quality characteristics of ground dried-pork meat products. Korean J Food Sci An, 35: 597-603.

Cumhur, Ö., Şeker, M., Sadıkoğlu, H. (2016). Freeze drying of turkey breast meat: Mathematical modeling and estimation of transport parameters. Dry Technol, 34: 584-594.

Duan, Z.H., Jiang, L.N., Wang, J.L., Yu, X.Y., Wang, T. (2011). Drying and quality characteristics of tilapia fish fillets dried with hot air-microwave heating. Food Bioprod Process, 89: 472-476.

Ensoy, U., Kolsarıc1, N., Candoğan, K., Karslooğlu, B. (2010). Changes in biochemical and microbiological characteristics of turkey sucuks as affected by processing and starter culture utilization. J Muscle Foods, 21: 142-165.

FAOSTAT. (2020). Livestock Primary. Retrieved from http://www.fao.org/faostat/en/\#data/QL (Accessed 28 May 2020).
Fu, X., Lin, Q., Xu, S., Wang, Z. (2015). Effect of drying methods and antioxidants on the flavor and lipid oxidation of silver carp slices. LWT Food Sci Technol, 61: 251-257.

Inchingolo, R., Cardenia, V., Rodriguez-Estrada, M.T. (2013). The effects of microwave heating on edible oils and lipid-containing food. Lipid Technol, 25: 59-61.

Jiang, N., Xu, B., Zhao, L., Huang, M., Zhou, G. (2016). Effects of high-temperature-short time (HTST) drying process on proteolysis, lipid oxidation and sensory attributes of Chinese drycured chicken. CyTA - J Food, 14: 440-448.

Konieczny, P., Stangierski, J., Kijowski, J. (2007). Physical and chemical characteristics and acceptability of home style beef jerky. Meat Sci, 76: 253-257.

Lemon, D.W. (1975). An improved TBA test for rancidity. New series Circular No:51, Halifax Laboratory, Halifax, Nova Scotia.

Maqsood, S., Al Haddad, N.A., Mudgil, P. (2016). Vacuum packaging as an effective strategy to retard off-odour development, microbial spoilage, protein degradation and retain sensory quality of camel meat. LWT - Food Sci Technol, 72: $55-62$.

Özbay-Doğu, S. (2016). Determination of effect of pre-treatments applying to round of meat $M$. semitendinosus) on microwave drying. Master thesis of Selçuk University (in Turkish), Turkey.

Półtorak, A., Wyrwisz, J., Moczkowska, M., Marcinkowska-Lesiak, M., Stelmasiak, A., Rafalska, U., Wierzbicka, A., Sun, D.W. (2015). Microwave vs. convection heating of bovine Gluteus Medius muscle: impact on selected physical properties of final product and cooking yield. Int J Food Sci Technol, 50: 958-965.

Porto-Fett, A.C.S., Call, J.E., Hwang, C.A., Juneja, V., Ingham, S., Ingham, B., Luchansky, J.B. (2009). Validation of commercial processes for inactivation of Escherichia coli O157: H7, Salmonella Typhimurium, and Listeria monocytogenes on the surface of whole-muscle turkey jerky. Poult Sci, 88: 1275-1281. 
Qu, C., He, Z., Wang, Z., Li, S., Wang, Z., Li, H. (2020). Effects of $\mathrm{NaCl}$ content and drying temperature on lipid oxidation, protein oxidation, and physical properties of dry-cured chicken. $J$ Food Sci, 85: 1651-1660.

Yalçın, M.Y., Şeker, M. (2016). Effect of salt and moisture content reduction on physical and microbiological properties of salted, pressed and freeze dried turkey meat. LWT-Food Sci Technol, 68: 153-159.
Zampiga, M., Tavaniello, S., Soglia, F., Petracci, M., Mazzoni, M., Maiorano, G., Meluzzi, A., Clavenzani, P., Sirri, F. (2019). Comparison of 2 commercial turkey hybrids: productivity, occurrence of breast myopathies, and meat quality properties. Poult Sci, 98: 2305-2315. 